\title{
Extracellular HIV-1 Tat up-regulates expression of matrix metalloproteinase-9 via a MAPK-NF-kB dependent pathway in human astrocytes
}

\author{
Sung Mi Ju', Ha Yong Song ${ }^{1}$, \\ Ji Ae Lee ${ }^{1}$, Su Jin Lee ${ }^{1}$, \\ Soo Young Choi ${ }^{1,2}$ and Jinseu Park ${ }^{1,2,3}$ \\ ${ }^{1}$ Department of Biomedical Science \\ ${ }^{2}$ Research Institute for Bioscience and Biotechnology \\ College of Natural Sciences \\ Hallym University \\ Chuncheon 200-702, Korea \\ ${ }^{3}$ Corresponding author: Tel, 82-33-248-2116; \\ Fax, 82-33-256-3420; E-mail, jinpark@ hallym.ac.kr \\ DOI 10.3858/emm.2009.41.2.011
}

Accepted 16 October 2008

Abbreviations: ADC, AIDS dementia complex; MMP, matrix metalloproteinases; Tat, transactivator of transcription

\begin{abstract}
The infiltration of monocytes into the CNS represents one of the early steps to inflammatory events in AIDS-related encephalitis and dementia. Increased activity of selected matrix metalloproteinases (MMPs) such as MMP-9 impairs the integrity of blood-brain barrier leading to enhanced monocyte infiltration into the CNS. In this study, we examined the effect of HIV-1 Tat on the expression of MMP-9 in CRT-MG human astroglioma cells. Treatment of CRT-MG cells with HIV-1 Tat protein significantly increased protein levels of MMP-9, as measured by Western blot analysis, zymography and an ELISA. Treatment of CRT-MG cells with HIV-1 Tat protein markedly increased mRNA levels of MMP-9, as analyzed by RT-PCR. Pretreatment of CRT-MG cells with NF- $\mathrm{KB}$ inhibitors led to decrease in Tat-induced protein and mRNA expression of MMP-9. Pretreatment of CRT-MG cells with MAPK inhibitors suppressed Tat-induced MMP-9 expression. Furthermore, HIV-1 Tat-induced expression of MMP-9 was significantly inhibited by neutralization of TNF- $\alpha$, but not IL-1 $\beta$ and IL-6. Taken together, our results indicate that HIV-1 Tat can up-regulate expression of MMP-9 via MAPK-NF- $k B$-dependent mechanisms as well as Tat-induced TNF- $\alpha$ production in astrocytes.
\end{abstract}

Keywords: astrocytes; gene products, tat; HIV; inflammation; matrix metalloproteinase 9; mitogenactivated protein kinases; NF- $\mathrm{BB}$; tumor necrosis factor- $\alpha$

\section{Introduction}

AIDS dementia complex (ADC) is a neurological disorder associated with HIV infection and affects up to $50 \%$ of adult AIDS patients. One of the characteristic features of ADC is the infiltration of monocytes into the CNS which represents one of the early steps to inflammatory events within the CNS (Ozdener, 2005; Rumbaugh and Nath, 2006). Although the processes in the monocyte infiltration into the CNS are complex, dysregulation of proinflammatory mediators such as cytokines, chemokines, and adhesion molecules and enzymes including matrix metalloproteinases (MMPs) during HIV-1 infection may accelerate the recruitment and trafficking of leukocytes into the CNS (Rappaport et al., 1999).

The HIV-1 Tat is a viral protein essential for expression and replication of the viral genome. HIV-1 Tat mRNA and protein have been detected in the brains of patients with ADC and HIV encephalitis (Wiley et al., 1996; Hudson et al., 2000). This Tat protein, released from the infected cells, has the ability to enter uninfected cells and exert its activity upon the responsive genes (Ensoli et al., 1993).

MMPs belong to the family of neutral endopeptidases that can mediate the degradation of extracellular matrix proteins and also degrade components of the blood-brain barrier (BBB), such as the EC basement membrane (Van den Steen et al., 2002). The activity of MMPs is strictly regulated at the levels of gene expression as well as proenzyme activation (Chakraborti et al., 2003). In addition, MMPs are controlled by naturally occurring tissue inhibitors of MMPs. It has been implicated that dysregulation of MMP activity during HIV infection is associated with disease progression by affecting the integrity of the extracellular matrix (Reviewed in Mastroianni and Liuzzi, 2007).

Previous studies reported that various MMPs 
activity such as MMP-2, 7, and 9 was increased in the cerebrospinal fluid of HIV-infected patients with neurological disorders (Sporer et al., 1998; Conant et al., 1999; Liuzzi et al., 2000; Suryadevara et al., 2003), suggesting that MMP activity is one of potential mediators involved in the BBB disruption. Although the exact source of MMPs activity in the CNS has not been elucidated, astrocytes, the major glial cells in the CNS and also one of major components of BBB, can act as a source of MMPs activity. Recently, it was demonstrated that when stimulated by HIV-1 virions, astrocytes can express the increased level of MMPs such as MMP-2 and MMP-9, which can contribute to inflammatory events within the CNS (Leveque et al., 2004). However, viral components responsible for expression of MMPs were not determined. In this study, we investigated the effect of extracellular HIV-1 Tat on the expression of MMP-9 and its underlying action mechanisms in astrocytes. We show that HIV-1 Tat increased the level of MMP-9 expression via MAPK-NF-кB-dependent mechanisms in astrocytes. We also show that Tat-mediated up-regulation of MMP-9 expression was dependent on TNF- $\alpha$ production induced by HIV-1 Tat.

\section{Results}

\section{Induction of MMP-9 expression by HIV-1 Tat in human astrocytes}

It was previously demonstrated that HIV-1 virion induces expression of MMP-9 by human astrocytes (Leveque et al., 2004). Besides HIV-1 virion, viral proteins such as HIV-1 Tat may contribute to up-regulate expression of MMPs which affect the integrity of BBB, leading to enhanced infiltration of monocytes into CNS (Conant et al., 2004). In this

A
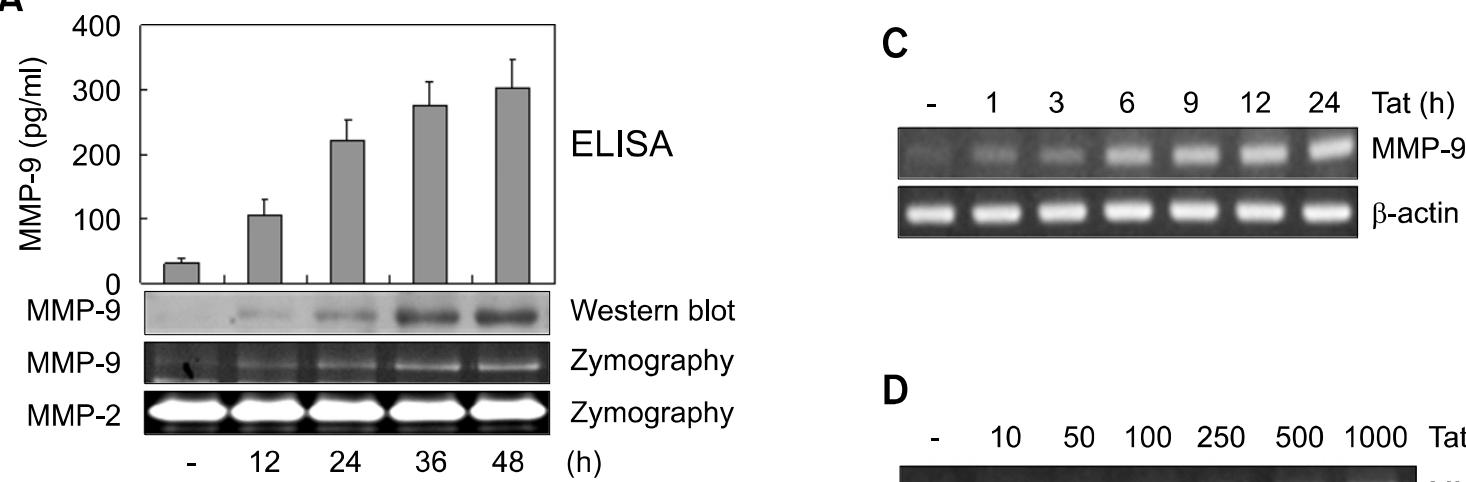

B
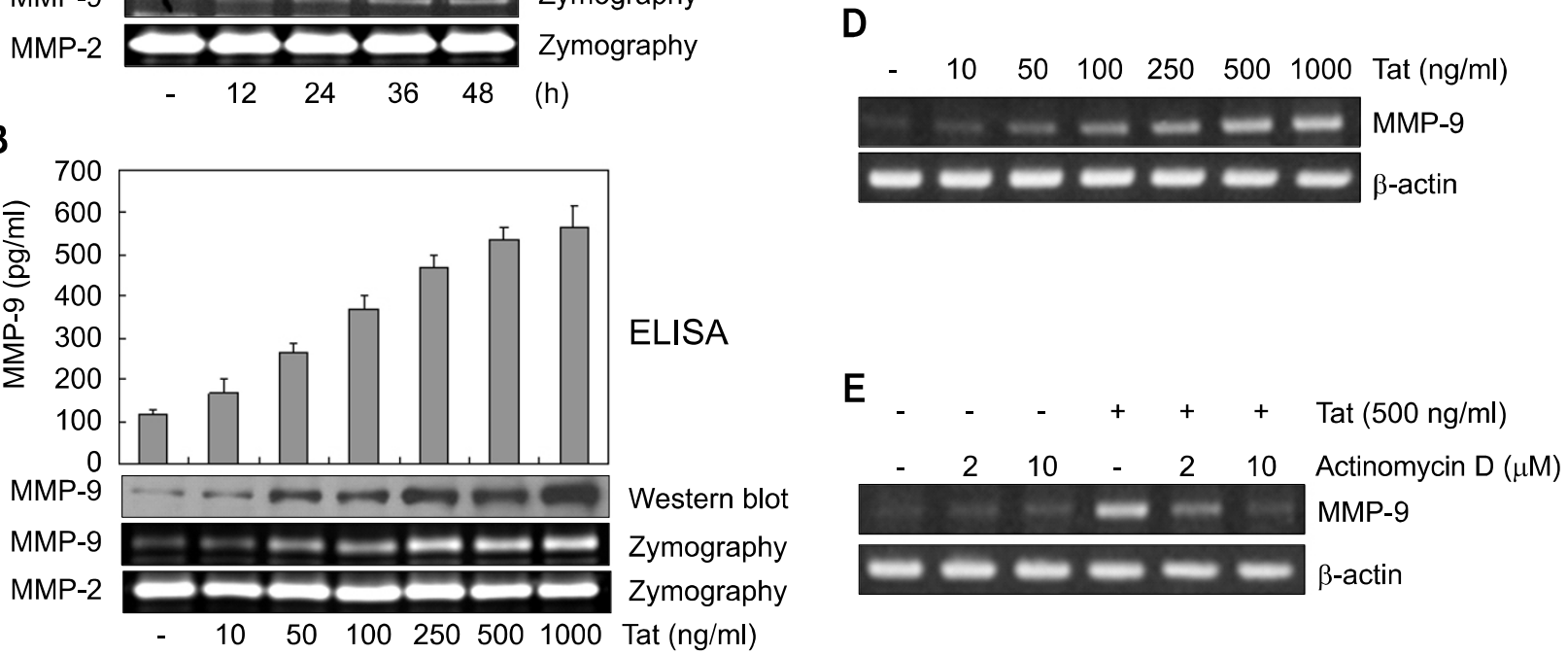

Figure 1. Up-regulation of expression of MMP-9 protein and mRNA in CRT-MG cells by HIV-1 Tat protein. CRT-MG cells were treated with $500 \mathrm{ng} / \mathrm{ml}$ HIV-1 Tat protein for various times (A) and various concentration of HIV-1 Tat protein for $48 \mathrm{~h}$ (B). Aliquots of culture media were collected and the concentration of MMP-9 was measured by ELISA (upper panel). Conditioned media were subjected to $8 \%$ SDS-PAGE with or without $0.2 \%$ gelatin. MMP-9 expression was determined by western blot (middle panel) and gelatinolytic activities of MMP-9 were determined by zymography (lower panel) as described in Methods. To analyze mRNA expression of MMP-9, CRT-MG cells were treated with $500 \mathrm{ng} / \mathrm{ml} \mathrm{HIV-1} \mathrm{Tat} \mathrm{protein} \mathrm{for} \mathrm{various} \mathrm{times} \mathrm{(C)} \mathrm{and} \mathrm{various} \mathrm{con-}$ centration of HIV-1 Tat protein (10-1,000 ng/ml) for $6 \mathrm{~h}(\mathrm{D})$. Total RNA was extracted and analyzed for expression of MMP-9 mRNA. (E) Inhibition of HIV-1 Tat-induced MMP-9 expression by actinomycin D. CRT-MG cells were pretreated with actinomycin D $(2,10 \mu \mathrm{g} / \mathrm{ml})$ for $1 \mathrm{~h}$ before treatment with HIV-1 Tat protein $(500 \mathrm{ng} / \mathrm{ml})$ for $6 \mathrm{~h}$. Total RNA was extracted. MMP-9 and actin mRNA were quantitated by RT-PCR using specific primers. RT-PCR products were analyzed by $1 \%$ agarose gel electrophoresis. 
study, we examined the effects of HIV-1 Tat upon MMP-9 expression in the human astrocyte cell line CRT-MG. CRT-MG cells were exposed to varying doses of HIV-1 Tat $(10-1,000 \mathrm{ng} / \mathrm{ml})$ and at $48 \mathrm{~h}$ later the culture supernatants were analyzed for expression of MMP-9 by ELISA and Western blot assay. In addition, gelatinolytic activity of MMP-9 in the culture supernatants was assessed by zymography. As shown in Figure 1A, a time-dependent increase in protein levels and gelatinolytic activity of MMP-9 was observed in CRT-MG cells stimulated with HIV-1 Tat $(500 \mathrm{ng} / \mathrm{ml})$. As shown in Figure $1 \mathrm{~B}$, the protein levels and gelatinolytic activity of MMP-9 increased in a dose-dependent manner. There was no change in MMP-2 expression in the same experimental conditions.

To examine whether HIV-1 Tat activates transcrip- tion of MMP-9 in CRT-MG cells, we analyzed the induction of MMP-9 mRNA expression in Tat-treated CRT-MG cells by RT-PCR. As shown in Figure $1 C$ and $D$, time- and dose-dependent increase in levels of MMP-9 mRNA was observed in CRT-MG cells following HIV-1 Tat treatment. In addition, treatment with actinomycin $\mathrm{D}$, an inhibitor of $\mathrm{mRNA}$ synthesis, markedly decreased expression of Tatinduced MMP-9 mRNA in CRT-MG cells (Figure $1 \mathrm{E})$. These results indicate that de novo mRNA synthesis is required for Tat-induced MMP-9 gene expression.

\section{NF- $\mathrm{KB}$ is responsible for induction of MMP-9 expression by HIV-1 Tat in human astrocytes}

MMP-9 expression is regulated by different trans-
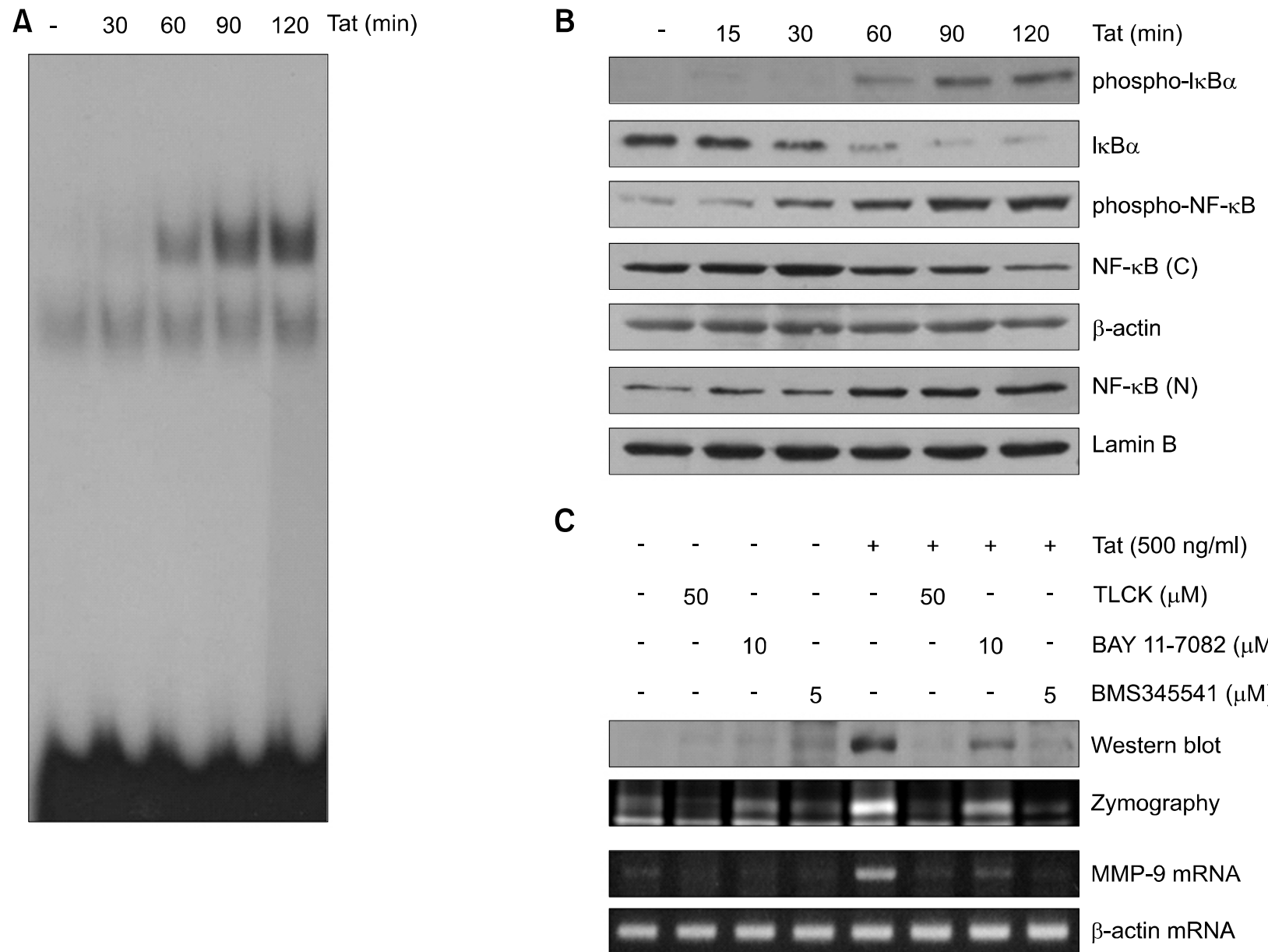

Figure 2. HIV-1 Tat induces NF- $\mathrm{B}$ B dependent up-regulation of MMP-9 in CRT-MG. (A) Nuclear extracts were prepared from the CRT-MG cells exposed to $500 \mathrm{ng} / \mathrm{ml} \mathrm{HIV-1}$ Tat protein for the indicated times and DNA binding activity of NF- $\mathrm{KB}$ in the nuclear extracts was measured by EMSA. (B) CRT-MG cells were exposed to $500 \mathrm{ng} / \mathrm{ml} \mathrm{HIV}-1$ Tat protein for the indicated times. Phosphorylation and degradation of $I_{\kappa} \mathrm{B}-\alpha$ and cytosolic and nuclear NF- $\mathrm{B}$ were analyzed by Western blotting. (C) CRT-MG cells were treated with HIV-1 Tat protein ( $500 \mathrm{ng} / \mathrm{ml}$ ) for $6 \mathrm{~h}$ (for MMP-9 mRNA) or $48 \mathrm{~h}$ (for MMP-9 protein) with or without pretreatment with NF- $\kappa$ B inhibitors (50 $\mu \mathrm{M}$ TLCK, $10 \mu \mathrm{M}$ BAY 11-7082, $5 \mu \mathrm{M}$ BMS345541) for $1 \mathrm{~h}$. Expression and activity of MMP-9 protein were determined by Western blot and zymograpy. MMP-9 mRNA expression was determined by RT-PCR. 
cription factors including NF-kB (Vincenti and Brinckerhoff, 2007). Previous studies demonstrated that extracellular HIV-1 Tat protein is associated with an increase in NF- $\mathrm{KB}$ binding activity in human astrocytes (Conant et al., 1996; Song et al., 2007b). To examine the involvement of NF-kB in MMP-9 expression, CRT-MG cells were treated with HIV-1 Tat, the activation of NF-kB was monitored by EMSA. DNA binding activity of NF-kB p65 in HIV-1 Tat treated CRT-MG cells was strongly induced (Figure 2A). The translocation of NF-kB was monitored by Western blot analysis. Nuclear accumulation of NF-KB p65 in HIV-1 Tat treated CRT-MG cells were significantly increased (Figure $2 B$ ). The translocation of NF- $\mathrm{KB}$ to the nucleus is preceded by the phosphorylation, ubiquitination, and subsequent proteasomal degradation of $I_{\kappa} \mathrm{B} \alpha$ (Gloire et al., 2006). Next, we examined HIV-1 Tat-induced signal cascade of NF- $\kappa B$ activation, such as $1 \kappa B \alpha$ phosphorylation and degradation by Western blot analysis using an antibody against phospho-specific $I_{\kappa} B \alpha$. Treatment of CRT-MG cells with HIV-1 Tat led to the rapid phosphorylation of $I_{\kappa} B \alpha$ and its subsequent degradation (Figure 2B). Pharmacological NF-KB inhibitors, TLCK, BAY 11-7082, and BMS345541 suppressed Tat-induced expression of MMP-9 and gelatinolytic activity of MMP-9 (Figure $2 C$ ). These results indicate that Tat-induced NF- $\kappa B$ activity is necessary for inducing MMP-9 expression in CRT-MG cells.

\section{HIV-1 Tat induced MAPK activation which is required for MMP-9 expression in CRT-MG}

Previous studies have indicated that extracellular HIV-1 Tat has a regulatory effect on the activity of MAPKs such as p38, JNK and ERK protein kinase in astrocytes (Kutsch et al., 2000, Song et al., 2007a). To examine HIV-1 Tat-induced MAPK activation, CRT-MG cells were exposed to HIV-1 Tat $(500 \mathrm{ng} / \mathrm{ml})$ for various times, and then MAPK activation was analyzed by Western blot analysis using phospho-specific antibodies against MAPK proteins. HIV-1 Tat induced phosphorylation of ERK, JNK and p38 protein kinase in a timedependent manner (Figure 3A). Pretreatment with MAPK inhibitors suppressed Tat-induced expression of MMP-9 mRNA, protein and gelatinolytic activity of MMP-9 (Figure 3B). These results indicate that Tat-induced MAPK activity is necessary for inducing MMP-9 expression in CRT-MG cells.

\section{Roles of cytokines in HIV-1 Tat-induced MMP-9 expression}

Since HIV-1 Tat stimulate the production of the
A

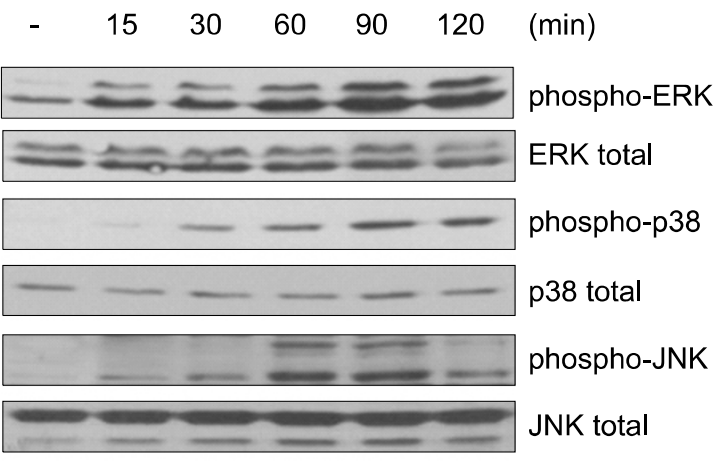

B
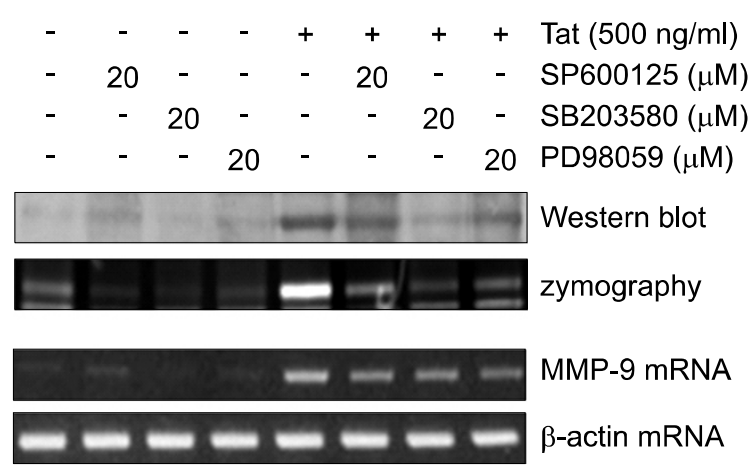

Figure 3. MAPKs activation is required for MMP-9 expression in CRTMG cells. (A) CRT-MG cells were treated with $500 \mathrm{ng} / \mathrm{ml} \mathrm{HIV-1} \mathrm{Tat} \mathrm{pro-}$ tein for the indicated time. Whole cell lysates were analyzed for MAPK protein activation by Western blot analysis using phospho-specific antibodies against MAPK proteins. Equal lane loading was confirmed by detecting blots for total MAPKs. (B) Cells were pretreated with SP600125 (JNK inhibitor), SB203580 (p38 inhibitor), or PD98059 (ERK inhibitor) for $1 \mathrm{~h}$ before adding $500 \mathrm{ng} / \mathrm{ml} \mathrm{HIV}-1$ Tat protein for $6 \mathrm{~h}$ (MMP-9 mRNA) or $48 \mathrm{~h}$ (MMP-9 protein). MMP-9 mRNA expression was determined by RT-PCR. MMP-9 expression and activity was determined by Western blot and zymograpy.

pro-inflammatory cytokines such as TNF- $\alpha$, IL-1 $\beta$ and IL-6 (Lafrenie et al., 1997; Nath et al., 1999), these cytokines might be involved in Tat-induced up-regulation of MMP-9 expression. Therefore, we measured the secreted protein levels of pro-inflammatory cytokines in the supernatants of Tat-treated CRT-MG cells by using specific ELISA kits. Treatment of Tat resulted in an increase in TNF- $\alpha$, and IL-6 protein levels, while Tat had no effects on the levels of IL-1 $\beta$ (Figure 4A). We next examined whether Tat induced MMP-9 expression through the action of these cytokines by using anti-cytokine antibodies. Preincubation of cells with anti-TNF- $\alpha$ antibody decreased the level of Tat-induced MMP-9 expression, as judged by Western blot analysis and zymography. In contrast, incubation of cells with anti-IL-1 $\beta$ or IL- 6 antibody had no effect 
A
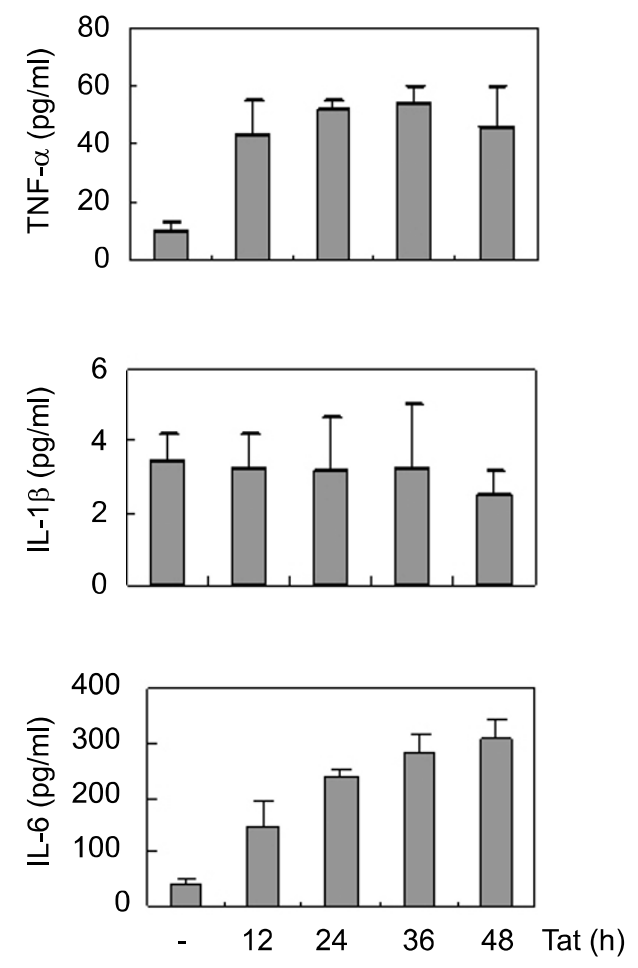

B

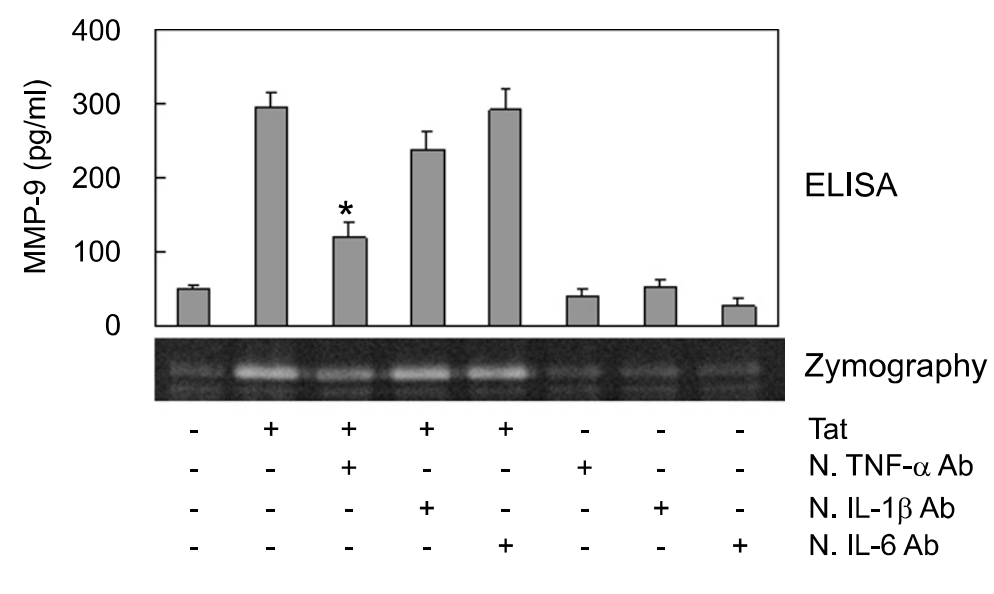

C

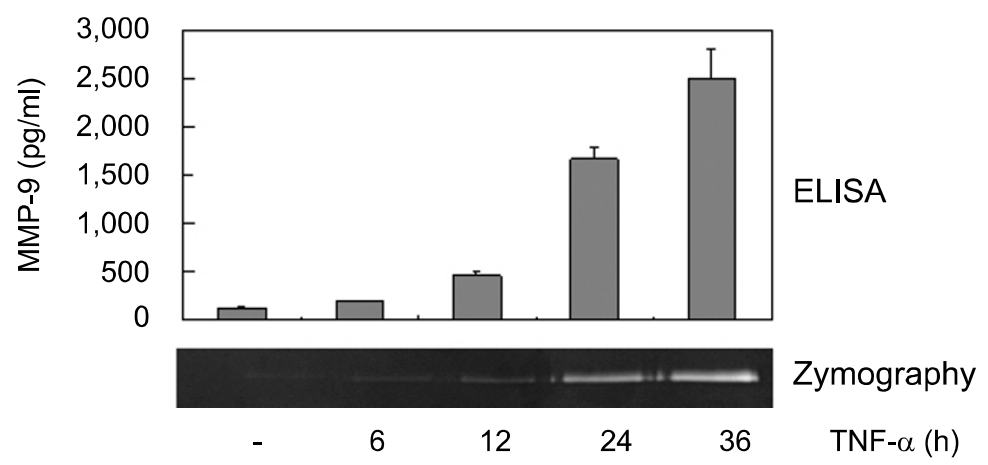

Figure 4. Extracellular HIV-1 Tat protein induces MMP-9 expression via TNF- $\alpha$ production. (A) Cytokine ELISA of the medium from CRT-MG cells treated with HIV-1 Tat. CRT-MG cells were treated with $500 \mathrm{ng} / \mathrm{ml}$ of HIV-1 Tat protein for the indicated periods. The culture supernatant was analyzed for the levels of cytokines using a sandwich ELISA with purified cytokines as concentration standard. (B) CRT-MG cells were treated with HIV-1 Tat protein in the presence of neutralizing anti-TNF- $\alpha$, anti-IL-1 $\beta$ or anti-IL-6 antibodies $(5 \mu \mathrm{g} / \mathrm{ml})$ for $48 \mathrm{~h}$. The culture supernatant was collected and analyzed for MMP-9 expression by ELISA and zymography. Asterisk indicates statistical significance at $P<0.001$ compared with cell treated with Tat alone. (C) CRT-MG cells were treated with TNF- $\alpha(10 \mathrm{ng} / \mathrm{ml})$ for the indicated periods. The culture supernatant was analyzed for the levels of MMP-9 protein and gelatinolytic activity by ELISA and zymography, respectively.

on the level of Tat-induced MMP-9 expression (Figure 4B). We next determined whether TNF- $\alpha$ itself induces MMP-9 in CRT-MG cells. CRT-MG cells were exposed to TNF- $\alpha$ for various times and the culture supernatants were analyzed for expression and gelatinolytic activity of MMP-9 by ELISA and zymography, respectively. As shown in Figure $4 \mathrm{C}$, the protein levels and gelatinolytic activity of MMP-9 increased in a time-dependent manner. This neutralization experiment suggests that MMP-9 expression induced by HIV-1 Tat was dependent on Tat-induced TNF- $\alpha$ production.

\section{Discussion}

Although the delicate balance between MMPs and their inhibitors in the CNS is maintained in the normal physiological conditions, excessive production of MMPs such as MMP-9 can degrade components of the BBB, such as laminin and type IV collagen, thereby increasing permeability of BBB (Yong et al., 1998). Recent study has shown that contact between HIV virions and astrocytes affected the secretion of MMPs and tissue inhibitors of metalloproteinase (TIMPs) in astrocytes (Leveque et al., 2004). Although HIV-1 can infect astrocytes in vivo, productive replication is limited in astrocytes (Tornatore et al., 1994; Takahashi et al., 1996). Therefore, viral proteins such as HIV-1 Tat and gp120 may contribute to upregulation of MMPs. Previous work has shown that HIV-1 Tat may regulate MMP-9 in monocytes (Lafrenie et al., 1996, 1997). However, little is known about HIV-1 Tat-mediated regulation of MMP-9 expression in astrocytes. In this study, we show that stimulation 
of astrocytes with HIV-1 Tat increased MMP-9 production with no change in MMP-2 via MAPKNF-kB-dependent mechanisms as well as Tat-induced TNF- $\alpha$ production.

Up-regulation of MMP-9 expression by HIV-1 Tat in astrocytes may lead to the disruption of BBB, resulting in the enhanced infiltration of leukocytes into the CNS. Previous studies have shown that expression of MMPs participates in infiltration of inflammatory cells into the CNS (Yong et al., 1998). Since MMP-9 expression is regulated by different signaling pathways according to the stimuli, we performed the experiments to analyze the activation of NF-KB and its signaling cascades. We showed that HIV-1 Tat-induced increase in expression and release of MMP-9 in CRT-MG cells is regulated at the transcriptional level (Figure 1). NF-KB inhibitors inhibited the expression of MMP-9 gene in astrocytes treated by HIV-1 Tat (Figure 2), suggesting Tat-mediated up-regulation of MMP-9 expression and release was dependent on an NF-kB-dependent pathway. Although the molecular mechanism by which HIV-1 Tat induces NF-kB activation is not clear, association of target molecules at the cell surfaces and extracellular HIV-1 Tat protein may trigger the possible signaling pathways that lead to the NF-KB activation. The MAPKs such as p38, JNK and ERK protein kinase are the principal components in the signaling cascades leading to activation of NF- $\mathrm{KB}$ upon various stimuli. Previous studies have shown that extracellular HIV-1 Tat can regulate the activity of MAPKs in astrocytes (Kutsch et al., 2000; Song et al., 2007a). MAPK inhibitors suppressed Tat-induced mRNA and protein expression of MMP-9 as well as gelatinolytic activity of MMP-9 (Figure 3B). These results indicate that MAPK activity is required for Tat-induced MMP-9 expression in CRT-MG cells.

As demonstrated in Figure 4, HIV-1 Tat is known to increase release of inflammatory cytokines such as TNF- $\alpha$ and IL-6 in astrocytes (Rappaport et al., 1999). To elucidate the possible involvement of these cytokines in Tat-mediated up-regulation of MMP-9 expression, we performed the neutralization experiments using neutralizing anti-TNF- $\alpha$, IL-1 $\beta$ or IL- 6 antibodies. Neutralizing anti-TNF- $\alpha$ antibodies inhibited Tat-induced MMP-9 expression and release. However, neutralizing anti-IL-1 $\beta$ or IL-6 antibodies did not suppress Tat-induced MMP-9 expression. These results demonstrate that TNF- $\alpha$ was directly involved in this process. Previous work has shown that HIV-1 Tat upregulates MMP-9 production which was dependent on Tatinduced TNF- $\alpha$ production in monocytes (Lafrenie et al., 1997). On the other hand, HIV-1 Tat-induced production of IL-1 $\beta$ or IL- 6 production was inde- pendent of TNF- $\alpha$ production in macrophages and astrocytes (Nath et al., 1999). These data indicate that HIV-1 Tat-induced MMP-9 expression but not IL-1 $\beta$ or IL- 6 production depends on TNF- $\alpha$ in both monocytes and astrocytes.

Because MMPs have both beneficial and detrimental effects on the neuropathogenesis, the outcomes of up-regulation of MMP-9 expression might be complex depending on the pathophyiological conditions (Agrawal et al., 2008). Previous study has shown that matrix metalloproteinase inhibitors suppressed HIV-1 Tat-induced neurotoxicity (Johnston et al., 2001). On the other hand, recent study provided the possibility that HIV-1 Tat interacts with MMPs, especially MMP-1 which can degrade Tat proteins, leading to the decrease in Tat-induced neurotoxicity and HIV transactivation (Rumbaugh et al., 2006). The ability of HIV-1 Tat to up-regulate MMP-9 as well as various inflammatory mediators such as cytokins/chemokines, adhesion molecules suggests the possible role of HIV-1 Tat as an important regulator in the trafficking of monocytes into the CNS (Rappaport et al., 1999). An understanding the mechanism by which HIV-1 Tat regulates MMP-9 production in the CNS may lead to novel therapies to control inflammatory processes during the development of HIV-induced neurological diseases.

\section{Methods}

\section{Cell culture}

CRT-MG human astroglial cells, derived from a neoplastic frontal lobe lesion, were maintained in RPMI 1640 medium supplemented with $10 \%(\mathrm{v} / \mathrm{v})$ heat-inactivated FBS, penicillin $\mathrm{G}(100 \mathrm{U} / \mathrm{ml})$, streptomycin $(100 \mu \mathrm{g} / \mathrm{ml})$ and L-glutamine $(2 \mathrm{mM})$ at $37^{\circ} \mathrm{C}$ in a humidified atmosphere containing $5 \% \mathrm{CO}_{2}$ and $95 \%$ air, as previously described (Song et al., 2007b).

\section{Reagents}

Actinomycin $D, N$ - $\alpha$-p-tosyl-L-lysine chloromethyl ketone hydrochloride (TLCK) SB203580, PD98059, BMS 345541 and gelatin were purchased from Sigma (St. Louis, MO). BAY 11-7082 and SP600125 were purchased from Calbiochem (La Jolla, CA). Primary antibodies against

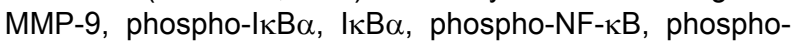
ERK, ERK, phospho-p38, p38, phospho-JNK and JNK (Cell Signaling Technology, Beverly, MA) were obtained commercially. HRP-conjugated anti-rabbit or goat antibodies were supplied by Sigma (St. Louis, MO). Neutralizing antibodies against TNF- $\alpha$, IL- $1 \beta$ and IL- 6 were purchased from R\&D Systems (Minneapolis, MN).

\section{Purification of recombinant HIV-1 Tat protein}

Recombinant HIV-1 Tat protein was purified under native 
conditions as described previously (Song et al., 2007b). Endotoxin levels for the Tat preparation were below the detection limit $(<0.1 \mathrm{EU} / \mathrm{ml})$ as tested by Limulus Amoebocyte Lysate assay (BioWhitaker, Walkersville, MD). The integrity and purity of the HIV-1 Tat proteins were assessed by SDS-PAGE followed by Coomassie blue staining. The biological activity of Tat was confirmed by a transactivation assay in HeLa cells transfected with a plasmid containing an HIV long terminal repeat (LTR)luciferase gene.

\section{Western blot analysis}

Cell lysates were prepared by incubating cells in lysis buffer $(125 \mathrm{mM}$ Tris- $\mathrm{HCl} \mathrm{pH} 6.8,2 \%$ SDS, 10\% v/v glycerol) at $4^{\circ} \mathrm{C}$ for $30 \mathrm{~min}$. Samples of fifty $\mu \mathrm{g}$ protein were separated on a $10 \%$ SDS-polyacrylamide gel. The proteins were electrotransferred to a nitrocellulose membrane, which was blocked with $10 \%$ dry milk in PBS. The membrane was probed with the indicated antibodies, and the immunoreactive bands were visualized by enhanced chemiluminescence (ECL; Amersham) as recommended by the manufacturer.

\section{RT-PCR analysis}

Total RNA was isolated from CRT-MG cells using a Trizol reagent kit (Invitrogen, Gaithersburg, MD) according to the manufacturer's instructions. The RNA $(2 \mu \mathrm{g})$ was reversibly transcribed with $10,000 \mathrm{U}$ of reverse transcriptase and 0.5 $\mu \mathrm{g} / \mu \mathrm{l}$ oligo-(dT) ${ }_{15}$ primer (Promega, Madison, WI). PCR amplification of cDNA aliquots was performed with the following sense and antisense primers $\left(5^{\prime} \rightarrow 3^{\prime}\right)$ : MMP-9 sense, GTGCTGGGCTGCTGCTTTGCTG; MMP-9 antisense, GTCGCCCTCAAAGGTTTGGAAT; $\beta$-actin sense, GCGGGAAATCGTGCGTGACATT; and $\beta$-actin antisense, GATGGAGTTGAAGGTAGTTTCGTG. PCR was performed in $50 \mu \mathrm{l}$ of $10 \mathrm{mM}$ Tris- $\mathrm{HCl}(\mathrm{pH} \mathrm{8.3),} 25 \mathrm{mM}$ $\mathrm{MgCl}_{2}, 10 \mathrm{mM}$ dNTP, $100 \mathrm{U}$ of Taq DNA polymerase, and $0.1 \mu \mathrm{M}$ of each primer and was terminated by heating at $70^{\circ} \mathrm{C}$ for $15 \mathrm{~min}$. PCR products were resolved on a $1 \%$ agarose gel and visualized with UV light after ethidium bromide.

\section{Assay of MMP-9 activity by gelatin zymography}

MMP-9 activity was assessed by gelatin zymography as described previously (Ma et al., 2001). Briefly, cultured cells $\left(8 \times 10^{5}\right.$ cells $/ 6$ well) were stimulated by HIV- 1 Tat for the indicated periods. Supernatants were collected and concentrated. Concentrated supernatants $(400 \mu \mathrm{l})$ were mixed with SDS sample buffer without reducing agent, and proteins were subjected to SDS-PAGE in $8 \%$ polyacrylamide gels containing $0.2 \%$ gelatin $(\mathrm{v} / \mathrm{v})$. After electrophoresis, the gels were washed twice in $10 \mathrm{mM}$ Tris- $\mathrm{Cl}(\mathrm{pH}$ 7.5 ) and $2 \%$ Triton $\mathrm{X}-100$ for $1 \mathrm{~h}$ at room temperature to remove the SDS, and then incubated for $24 \mathrm{~h}$ at $37^{\circ} \mathrm{C}$ in a buffer containing $10 \mathrm{mM}$ Tris- $\mathrm{Cl}(\mathrm{pH} 7.5), 10 \mathrm{mM} \mathrm{CaCl}_{2}$ and $150 \mathrm{mM} \mathrm{NaCl}$. The gels were stained with Coomassie Brilliant Blue R250 (Bio-Rad, CA) $(0.25 \%)$ for $30 \mathrm{~min}$, then destained for $1 \mathrm{~h}$ in a solution of acetic acid and methanol.
Proteolytic activity was evident as clear bands (zone of gelatin degradation) against the blue background of stained gelatin.

\section{Measurement of cytokines and MMP-9 protein by ELISA}

CRT-MG cells were cultured in the presence of HIV-1 Tat for the indicated periods, and MMP-9, TNF- $\alpha, \mathrm{IL}-1 \beta$ and IL- 6 in the supernatants were measured by an ELISA kit (R\&D Systems, Minneapolis, MN), according to the manufacturer's instructions.

\section{Electrophoretic mobility shift assay (EMSA)}

Nuclear extracts of CRT-MG cells were prepared and analyzed for NF- $\kappa B$ binding activity by EMSA as described previously (Song et al., 2007b). An NF-KB consensus oligonucleotide (Promega) was used in the EMSA. The complementary oligonucleotide was annealed and endlabeled with $\left[\gamma_{-}{ }^{32}\right.$ P]ATP using T4 polynucleotide kinase. EMSA was performed in a total volume of $20 \mu \mathrm{l}$ at $4^{\circ} \mathrm{C}$. Five micrograms of nuclear extracts were equilibrated for $15 \mathrm{~min}$ in binding buffer (10 mM Tris- $\mathrm{HCl}, \mathrm{pH} 8.0,75 \mathrm{mM}$ $\mathrm{KCl}, 2.5 \mathrm{mM} \mathrm{MgCl}, 0.1 \mathrm{mM}$ EDTA, $10 \%$ glycerol, $0.25 \mathrm{mM}$ DTT) and $1 \mu \mathrm{g}$ of poly $\mathrm{dl} / \mathrm{dC}$. ${ }^{32} \mathrm{P}$-labeled oligonucleotide probe $(20,000 \mathrm{cpm})$ was then added and the reaction was incubated on ice for an additional $20 \mathrm{~min}$. Bound and free DNA were then resolved by electrophoresis on a $6 \%$ native polyacrylamide gel in TBE buffer $(89 \mathrm{mM}$ Tris- $\mathrm{HCl}, 89 \mathrm{mM}$ boric acid, and 2 mM EDTA).

\section{Statistical analysis}

The results were expressed as the mean \pm SEM from at least three independent experiments. The values were evaluated via one-way ANOVA, followed by Duncan's multiple range tests using GraphPad Prism 4.0 software (GraphPad Software, Inc., SanDiego, CA). Differences were considered to be significant at $P<0.001$.

\section{Acknowledgments}

This work was supported in part by a Next Generation Growth Engine Program Grant from the Korean Science and Engineering Foundation, and in part by a Regional Innovation Center Grant from the Korean Ministry of Commerce, Industry and Energy.

\section{References}

Agrawal SM, Lau L, Yong VW. MMPs in the central nervous system: where the good guys go bad. Semin Cell Dev Biol 2008;19:42-51

Chakraborti S, Mandal M, Das S, Mandal A, Chakraborti T. Regulation of matrix metalloproteinases: an overview. Mol Cell Biochem 2003;253:269-85

Conant K, Ma M, Nath A, Major EO. Extracellular human immunodeficiency virus type 1 Tat protein is associated with 
an increase in both NF-kappa B binding and protein kinase C activity in primary human astrocytes. J Virol 1996;70: 1384-9

Conant K, McArthur JC, Griffin DE, Sjulson L, Wahl LM, Irani DN. Cerebrospinal fluid levels of MMP-2, 7, and 9 are elevated in association with human immunodeficiency virus dementia. Ann Neurol 1999;46:391-8

Conant K, St Hillaire C, Anderson C, Galey D, Wang J, Nath A. Human immunodeficiency virus type 1 Tat and methamphetamine affect the release and activation of matrix-degrading proteinases. J Neurovirol 2004;10:21-8

Ensoli B, Buonaguro L, Barillari G, Fiorelli V, Gendelman R, Morgan RA, Wingfield P, Gallo RC. Release, uptake, and effects of extracellular human immunodeficiency virus type 1 Tat protein on cell growth and viral transactivation. J Virol 1993;67:277-87

Gloire G, Legrand-Poels S, Piette J. NF-kappaB activation by reactive oxygen species: fifteen years later. Biochem Pharmacol 2006;72:1493-505

Hudson L, Liu J, Nath A, Jones M, Raghavan R, Narayan O, Male D, Everall I. Detection of the human immunodeficiency virus regulatory protein tat in CNS tissues. J Neurovirol 2000;6:145-55

Johnston JB, Zhang K, Silva C, Shalinsky DR, Conant K, Ni W, Corbett $D$, Yong VW, Power C. HIV-1 Tat neurotoxicity is prevented by matrix metalloproteinase inhibitors. Ann Neurol 2001;49:230-41

Kutsch O, Oh J, Nath A, Benveniste EN. Induction of the chemokines interleukin- 8 and IP-10 by human immunodeficiency virus type 1 tat in astrocytes. J Virol 2000;74: 9214-21

Lafrenie RM, Wahl LM, Epstein JS, Hewlett IK, Yamada KM, Dhawan S. HIV-1-Tat modulates the function of monocytes and alters their interactions with microvessel endothelial cells. A mechanism of HIV pathogenesis. J Immunol 1996; 156:1638-45

Lafrenie RM, Wahl LM, Epstein JS, Yamada KM, Dhawan S. Activation of monocytes by HIV-Tat treatment is mediated by cytokine expression. J Immunol 1997;159:4077-83

Leveque T, Le Pavec G, Boutet A, Tardieu M, Dormont D, Gras $G$. Differential regulation of gelatinase $A$ and $B$ and TIMP-1 and -2 by TNFalpha and HIV virions in astrocytes. Microbes Infect 2004;6:157-63

Liuzzi GM, Mastroianni CM, Santacroce MP, Fanelli M, D'Agostino C, Vullo V, Riccio P. Increased activity of matrix metalloproteinases in the cerebrospinal fluid of patients with HIV-associated neurological diseases. J Neurovirol 2000;6: 156-63

Ma Z, Qin H, Benveniste EN. Transcriptional suppression of matrix metalloproteinase-9 gene expression by IFN-gamma and IFN-beta: critical role of STAT-1alpha. J Immunol 2001; $167: 5150-9$

Mastroianni CM, Liuzzi GM. Matrix metalloproteinase dysregulation in HIV infection: implications for therapeutic strategies. Trends Mol Med 2007;13:449-59
Nath A, Conant K, Chen P, Scott C, Major EO. Transient exposure to HIV-1 Tat protein results in cytokine production in macrophages and astrocytes. A hit and run phenomenon. J Biol Chem 1999;274:17098-102

Ozdener H. Molecular mechanisms of HIV-1 associated neurodegeneration. J Biosci 2005;30:391-405

Rappaport J, Joseph J, Croul S, Alexander G, Del Valle L, Amini S, Khalili K. Molecular pathway involved in HIV1-induced CNS pathology: role of viral regulatory protein, Tat. J Leukoc Biol 1999;65:458-65

Rumbaugh J, Turchan-Cholewo J, Galey D, St Hillaire C, Anderson C, Conant K, Nath A. Interaction of HIV Tat and matrix metalloproteinase in HIV neuropathogenesis: a new host defense mechanism. FASEB J 2006;20:1736-8

Rumbaugh JA, Nath A. Developments in HIV neuropathogenesis. Curr Pharm Des 2006;12:1023-44

Song HY, Ju SM, Lee JA, Kwon HJ, Eum WS, Jang SH, Choi SY, Park J. Suppression of HIV-1 Tat-induced monocyte adhesiveness by a cell-permeable superoxide dismutase in astrocytes. Exp Mol Med 2007a;39:778-86

Song HY, Ryu J, Ju SM, Park LJ, Lee JA, Choi SY, Park J. Extracellular HIV-1 Tat enhances monocyte adhesion by up-regulation of ICAM-1 and VCAM-1 gene expression via ROS-dependent NF-kappaB activation in astrocytes. Exp Mol Med 2007b;39:27-37

Sporer B, Paul R, Koedel U, Grimm R, Wick M, Goebel FD, Pfister HW. Presence of matrix metalloproteinase- 9 activity in the cerebrospinal fluid of human immunodeficiency virus-infected patients. J Infect Dis 1998;178:854-7

Suryadevara R, Holter S, Borgmann K, Persidsky R, LabenzZink C, Persidsky Y, Gendelman HE, Wu L, Ghorpade A. Regulation of tissue inhibitor of metalloproteinase-1 by astrocytes: links to HIV-1 dementia. Glia 2003;44:47-56

Takahashi K, Wesselingh SL, Griffin DE, McArthur JC, Johnson RT, Glass JD. Localization of HIV-1 in human brain using polymerase chain reaction/in situ hybridization and immunocytochemistry. Ann Neurol 1996;39:705-11

Tornatore C, Chandra R, Berger JR, Major EO. HIV-1 infection of subcortical astrocytes in the pediatric CNS. Neurology 1994;44:481-7

Van den Steen PE, Dubois B, Nelissen I, Rudd PM, Dwek RA, Opdenakker G. Biochemistry and molecular biology of gelatinase $B$ or matrix metalloproteinase-9 (MMP-9). Crit Rev Biochem Mol Biol 2002;37:375-536

Vincenti MP, Brinckerhoff CE. Signal transduction and cell-type specific regulation of matrix metalloproteinase gene expression: can MMPs be good for you? J Cell Physiol 2007;213:355-64

Wiley CA, Baldwin M, Achim CL. Expression of HIV regulatory and structural mRNA in the central nervous system. AIDS 1996;10:843-7

Yong VW, Krekoski CA, Forsyth PA, Bell R, Edwards DR. Matrix metalloproteinases and diseases of the CNS. Trends Neurosci 1998;21:75-80 